\title{
Construction and Research of College Students' Educational Management Ecosystem in the Micro Era
}

\author{
Baofeng Wang* \\ College of Mechanical and Electrical Engineering, Shihezi University, Shihezi 832000, Xinjiang, China. \\ E-mail: wangbaofeng2010@sina.com
}

\begin{abstract}
With the acceleration of educational development and technological development, society continues to advance, technology continues to innovate, and related concepts are also updated. The network is playing an increasingly important role in people's social production and life. With the help of the Internet and related information technology applications, education is provided with a broader resource and interactive platform, and related technology and concept updates have also brought new opportunities and challenges to the development of education. With the advent of the micro era, the Microsoft platform has brought great convenience to people's life, study and work. In the micro era, some new problems have emerged in education management. In this regard, it is necessary to clarify the impact of college student education management in the micro era, and actively explore specific countermeasures for the construction of the college student education management ecosystem in the micro era.
\end{abstract}

Keywords: Micro Era; College Students; Education Management; Ecosystem; Construction

In the micro era, people's life and learning methods have undergone significant changes, which are far from the past and learning mode. The micro era has many connotations, and the characteristics of the sweaty Microsoft era and the micro-culture era are in this era. People's ways of socializing have changed. With the help of related software applications, remote information dissemination and interaction can be realized, and communication efficiency can be improved. In the network platform, people can also obtain the resources they need anytime and anywhere to carry out independent learning and promotion. In the micro era, people's learning no longer only relies on books, but smartphones, computers, tablets, etc. to achieve diversified learning. Related information resources are broader, more selective, and high-quality resources are available. For the education management of colleges and universities, it also provides brand-new ways and methods. The education ecological management of college students in the micro era is full of opportunities and challenges.

\section{The impact of the micro era on the education management ecology of college students}

\subsection{New challenges brought to the management of college students}

The development of the Internet and micro-cultural forms have a greater impact on the values and behavior habits of young college students. In the era of new media, the characteristics of information diversification, non-standardization, and interactivity are very obvious. Everyone can be producers and disseminators of entertainment news self-media information, etc. Because of its high degree of freedom and diverse opinions, it has a huge impact on the value of young college students. On the whole, the self-media culture will have an impact on the thoughts and behaviors of college students, with strong dynamics, diversified development, and strong continuity. For example, micro-culture is constantly improving its quality during development, and its dynamic characteristics will continue to affect the thoughts and behaviors of college students, and the content of the communication will make the thinking of college students more diverse.

Copyright (C) 2020 Baofeng Wang

doi: $10.18282 /$ le.v9i6.1294

This is an open-access article distributed under the terms of the Creative Commons Attribution Non-Commercial License

(http://creativecommons.org/licenses/by-nc/4.0/), which permits unrestricted non-commercial use, distribution, and reproduction in any medium, provided the original work is properly cited. 
Under the background of micro-culture, the openness and sharing of resources have increased, and related management methods have also changed. The education management of students is no longer carried out in the traditional rigid restraint mode, and new challenges are presented to management. In the micro era, it is more difficult for university administrators to manage university students. The relevant university administrators cannot promptly screen the relevant false information and bad information in the network, and cannot create a healthy cultural atmosphere and learning environment for university students. The temptation for university students increase. As the penetration rate of smartphones, computers, and tablets among college students increases, they can access more network news pushes anytime and anywhere. The impact of this information and culture on college students is inevitable and brings new challenges to college student education management.

\subsection{It is more difficult to build a good class style}

In the micro era, it is necessary to build a good class atmosphere among college students, so as to promote the development of college student education and enhance the effectiveness of college student management. It can be seen that a good learning environment has a greater impact on the learning of college students, enabling students to learn and improve in such a group, cultivate good learning habits, and improve learning effectiveness. However, in the micro-era, college students are not lacking in resources, but professional talents are relatively insufficient. Because the micro-cultural environment will have a certain impact on the construction of the style of study, it is necessary to strengthen the development of related management work and master how to deal with the impact of network culture in order to be able to better deal with the challenges of college student education management under the background of micro-culture, to build a good class atmosphere for college students under the network environment.

\section{Countermeasures for the construction of the education and management ecosystem of college students in the micro era}

\subsection{Strengthen the education and guidance of network culture and cultivate correct ideas}

In the context of micro-culture, the development of related network culture and social culture will have a certain impact on the ideology and understanding of college students. To strengthen the education and management of college students, it is necessary to improve college students' knowledge of network security and civilized Internet access, so that college students can view the complex network environment correctly and a correct view of network culture should be established. College ideological and political education should make network culture education one of the key teaching contents, so that college students can understand, perceive, and realize the potential risks to network security such as network leakage, smartphone information leakage and online shopping risks, then improve the security awareness and actively carry out a series of activities for college students to build network security together and share network civilization. In addition, in the education and management of college students, colleges and universities should pay attention to strengthening the cultivation of college students' civilized online behaviors and ideological concepts, so that the majority of college students can learn to distinguish right from wrong in the online world, and how to correctly treat some online behaviors and phenomena, so that college students can view the Internet develop the influence on the behavior, ideology and other aspects of college students themselves, so that college students can improve their recognition ability, better use the advantages brought by network development, avoid the erosion of bad culture in the network, and maintain the physical and mental health of college students in the network environment. Through active guidance and education, college students should correct their thoughts and attitudes about the Internet, use the Internet correctly, use the Internet in a civilized manner, and know how to use the Internet to assist learning and promote self-growth, instead of indulging in the Internet culture and being affected by bad habits.

\subsection{Innovate teaching models and build a new ecology of teaching development}

In the era of micro-culture, education is the key to strengthening the construction of the education management ecosystem for college students. Related teaching work should focus on breaking through traditional curriculum teaching models and strengthening the application of innovative teaching ecological models. The development of the micro-culture era has brought many new curricula teaching concepts and teaching models. Informatization teaching has become an important development trend. The application of micro-classes, MOOCs, flipped classrooms, and electronic whiteboards in college curriculum education continue to increase. Therefore, relevant universities must strengthen the inno- 
vation of teaching methods if they want to build an ecosystem of undergraduate education management. In actual teaching, teachers should pay attention to the application of multiple curriculum teaching models, stimulate students' interest in learning, incorporate information-based teaching equipment and technology in the classroom, promote the integration of curriculum teaching resources, and improve the design and quality of curriculum teaching. Under such a background of teaching ecology, college students' interest in curriculum learning can be stimulated, learning efficiency can be improved, and it can also promote college students' independent learning and deepen the concept of lifelong learning.

\subsection{Strengthen the informatization of education management and improve the informatization literacy of teachers}

In the era of micro-culture, the development and application of information technology and Internet technology have put forward new requirements for teachers of related courses. It is not only necessary to actively introduce information management systems and software in the education and management of college students, but also apply information management methods to improve management efficiency. Teachers are also required to have a certain degree of information education and management quality, which puts forward higher requirements for teachers in the new era. In this regard, relevant colleges and universities should strengthen the construction of an educational management information ecological system, and pay attention to the improvement of teacher information teaching and management skills.

At present, the construction of related education management information websites, software, and information management systems is developing rapidly. In view of the account usage and permissions of the relevant education management information network background, teacher training should be strengthened, and the new functions of the website background will be demonstrated. And explain, let the relevant university teachers learn the data filling and the problem-solving countermeasures generated during the installation and use of the class multimedia system monitoring software, and accumulate experience and practices similar to the installation and debugging of the class multimedia system monitoring software. By actively strengthening the education informatization work management system and the application of the education informatization work progress information system, it is possible to accumulate teachers' informatization teaching and management experience, and improve the level and quality of the construction of the education management ecosystem for college students in the micro era.

\section{Conclusion}

The advent of the micro era has brought fundamental changes to the education management ecology of college students. There are both opportunities and challenges for the development of college student education. In the micro era, relevant universities should strengthen the construction of a new ecosystem of college student education management, actively pay attention to the integration and application of educational resources in the micro-era, and use the technology and concept development results of the micro-era to promote the continuous improvement of curriculum teaching quality, the development of teaching innovation, and a new ecology of education management.

\section{References}

1. Zhao W. Research on the management of entrepreneurship education in higher vocational colleges from the perspective of ecosystem. Journal of Shandong Institute of Agricultural Engineering 2018; 35(04): 161-162.

2. Wang Y, Zhang S. Building a "Four-in-One" convergent ecosystem——On the cultivation model of college students' innovation and entrepreneurship. Science and Technology Entrepreneurship Monthly 2017; 30(19): 52-55.

3. Chen R. Research on the management of entrepreneurship education in higher vocational colleges from the perspective of ecosystem. Journal of Heilongjiang Institute of Education 2017; 36(09): 49-51.

4. Xiang D, Zheng Z. Refined management of entrepreneurial education ecosystem and professional associations in colleges and universities. Continuing Education Research 2017; (07): 19-21.

5. Zhu Z. Niche overlap and niche empty field: The dislocation development of colleges and universities from the perspective of ecosystem. Heilongjiang Higher Education Research 2013; 31(04): 31-33.

6. Cen J, Yuan H. Regional education informatization breakthrough__ Analysis of the construction practice of education informatization ecosystem in Foshan City. Modern Education Technology 2009; 19(02): 128-132. 